\title{
CRITICAL CITIZENSHIP AND HIGHER EDUCATION CURRICULA
}

\author{
LEGACIES AND PROSPECTS
}

\section{INTRODUCTION}

In this chapter we explore three related issues. Firstly, we briefly refer to some of the legacies from South Africa's colonial and apartheid past, especially as they pertain to university curricula and student learning; secondly, we point to links between critical citizenship and higher education curricula; and thirdly, we refer to a number of relevant examples where critical citizenship education was recently introduced into core curricula by a number of South African universities.

\section{PAST SOUTH AFRICAN LEGACIES}

The legacy of colonialism and apartheid has left ingrained scars in the social conscience of South African citizens. The strong colonial influences that came with Dutch and British occupations of the Cape Colony brought with it a Western orientation. Black Africans, for many decades seen as "the other", were politically dominated and remained poorly integrated into this Western orientation. This "otherness" was exacerbated in apartheid South Africa, where cultures were deliberately kept apart and the richness of other cultures was completely overlooked, being seen as a threat to the hegemony of Western culture. Even though the tables were officially turned in 1994, the remnants of previous dominant ideologies and discourses inadvertently continue to affect the present.

The past emphasis on differences between cultural groups has been so intense that even now, more than 20 years after apartheid, the combination of multicultural groups of students in higher educational environments proves to be challenging. Incidents of miscommunication between students, teachers, and students and teachers are numerous, and have on various occasions led to claims of discrimination, harmful 
conduct and racism against and within higher education institutions (see for instance the Soudien Report in HESA 2008). Teaching, learning and student life within this context are hence sensitive, complex and challenging issues. Only as recently as 2013, the South African Department of Higher Education and Training in South Africa has stated that in the future, mandatory and credit-bearing anti-racism and citizenship education programmes should be developed in all public colleges and state-supported universities (DHET 2014).

The inherent complexity of teaching and learning within this context has led to consideration of the effect of perceptions and attitudes regarding social transformation' ${ }^{1}$ within an evolving multicultural higher education environment. In a comprehensive report on social transformation in higher education (Reddy 2004), the history and new position of social transformation in higher education institutions were mapped out under the following headings: (a) the pre-1994 apartheid period and (b) the post-1994 period, which includes transition, higher education policy and impact stages. Reddy (2004) refers to crucial legislative policies and papers that shaped transformation in higher education in South Africa such as the work of the National Commission on Higher Education (NCHE 1996) and the Higher Education White Paper 3: A Programme for the Transformation of Higher Education (DoE 1997). Reddy (2004:39) remarks that, even though much progress has been made on the legislative policy front, executing these policies in practice has been a slow, difficult and ambiguous process; "impressive gains sit alongside old patterns reproducing themselves both within the higher education sector and in the relations between this sector and society".

Even though the apartheid government and its attendant university policies have been abolished on paper, the perceptions in people's minds do not automatically change. An ingrained perception is often not consciously noticeable, because it is taken as the norm, and these perceptions and attitudes can therefore influence the writing of a higher education curriculum in subtle and complex ways. In higher education, the curriculum is seen as a device to shape student development. It is often shaped by the attitudes and perceptions of the person(s) deciding on the curriculum, by what is included and left out or by the culture that is more prominent in the type of projects or

1 According to Makgoba (1997), social transformation is a noticeable change in form or character. He argues that transformation is not reform, but rather a "blueprint change". Fourie (1999:277) refers to the work of Harvey and Green (1993:24), who believe that " $[\mathrm{t}]$ ransformation is not restricted to apparent or physical transformation but also includes cognitive transcendence". 
examples used. ${ }^{2}$ Barnett (2000:264, 2004:249) suggests that recognising complexity in the dimensions of human being(s) within a multicultural and global world could be the way forward. In his opinion, the role of the curriculum is to engage with and react to the challenges of a super complex and postmodern world (Barnett 2004:250).

These challenges, as mentioned by Barnett, involve bridging the gap between individuals involved in a learning environment. It is perhaps experienced more in confronting what is happening in the everyday interaction between people, and not so much in the writing of policies or curricula per se. The colonial/apartheid and post-colonial and post-apartheid past have created mental contrasts that easily confuse, and are therefore often silenced (Jansen 2009). The results of the silence often manifest in anger or a feeling of loss of power, or the opposite: of living in the illusion or fantasy that nothing has changed. Apart from the knowledge and skills that are developed in education, one should also look at the person studying (the student as a person) or lecturing (the lecturer as a person) (Barnett, Parry \& Coate 2001). There is therefore a crucial relationship between knowing and being (Barnett et al. 2001:445) and therefore changes in perceptions and attitudes might not take place without making the implicit explicit and prominent.

Against this historical background, it seems imperative to also look at the issue of student capabilities or attributes. According to Walker (2008a:28), a capability is "a potential functioning", or what one really manages to accomplish; or, as described by Sen (2004:78), "what we are free to do and free to be". Sen (2004:80) is against a fixed list of capabilities for all societies, for a "fixed forever list of capabilities would deny the possibility of progress in social understanding and also go against the productive role of public discussion, social agitation, and open debates". For Barnett (2009), attributes or capabilities such as integrity, respect for others, selfreflection or generosity are often seen as implicit in a curriculum, while Nussbaum (2002) refers to attributes or capabilities that include the ability to criticise your own traditions, mutual respect for other opinions, thinking as a citizen of the world and not only locally and imagining yourself in the shoes of others - or what she calls the "narrative imagination". Nussbaum (2003:84-86) also differentiates between "internal capabilities" and "combined capabilities", where an internal capability to function also depends on external suitable conditions. Combined capabilities need to be developed to overcome, for instance, historical social barriers.

2 Barnett and Coate (2008) refer to a hidden curriculum or a curriculum within a curriculum, where what is said on paper and in policy documents not always corresponds with what is happening in actual educational interactions. 
Given the history of higher education in South Africa and the question of what student capabilities the country needs for its future, one could begin to ask whether it is at all possible to facilitate the learning of graduate attributes such as integrity, respect for others and self-reflection - to name but three - on a university-wide scale. Can the intended learning of such generic capabilities automatically take place, does it happen by "a process of osmosis" from lecturer to student, or is it merely assumed learning that takes place in the educational environment (mostly outside lectures) of a university? Is it automatically learnt through the example of how an organisation, faculty or lecturer operates? Walker (2008b:156) argues that we cannot guarantee that transformation or change will take place in an educational setting, but she also states that "[w]e ought to provide the conditions - 'educate in such a way' - that educational development that supports human flourishing is enabled".

We therefore continue with the argument that critical citizenship, both as a concept and an organising framework, may have the potential to address the subtle complexities involved in South Africa's current higher educational context. We also believe that a critical citizenship perspective in university curricula may assist in addressing both local and global calls for social transformation. The concept of critical citizenship is therefore explored next.

\section{THE CONCEPT OF CRITICAL CITIZENSHIP EXPLORED}

In ancient Greece, a citizen belonged to a city state, which has since become a nation state. Today's citizen can belong to such a nation state or choose to become a world citizen who associates with the world in general, instead of with a certain nation. According to Yuval-Davis (1999:119), citizenship is a complex and multi-layered concept that may also include local, ethnic or cultural citizenship. In South Africa, the national Department of Education's (DoE 2002:8) revised National Curriculum Statement policy document earlier described citizenship in terms of participation, but also in terms of "respect for democracy, equality, human dignity, life and social justice". Although citizenship comes with certain legal rights, for instance the right to vote, it also encompasses attendant obligations and responsibilities towards the nation or community. Citizenship therefore appears to be a multidimensional concept generally based on the acknowledgement of, and respect for, difference a key ingredient to a socially just society. ${ }^{3}$

3 Also compare the South African Constitution in this respect. Section 3(2) in particular states that: "All citizens are - (a) equally entitled to rights, privileges and benefits of citizenship; and (b) equally subject to the duties and responsibilities of citizenship". 
Within this definition of citizenship it is clear that marginalisation, exclusion, stigmatisation and "othering" of citizens, as played out during the colonial and apartheid years in South Africa, are some of the challenges that gave rise to citizenship education. Citizenship education is based on the promotion of a "common set of shared values (e.g. tolerance, human rights and democracy), which prepare young people to live together in diverse societies and which reject the divisive nature of national identities" (Johnson \& Morris 2010:77). Citizenship education also "contributes to the promotion of social justice, social reconstruction and democracy" (Johnson \& Morris 2010:78). What is lacking in such a definition, however, is a critical perspective.

By adding the term "critical" to citizenship, such education comes to include the ideas of critical thinking and critical pedagogy (Johnson \& Morris 2010:77-78). Critical thinking generally refers to higher-order thinking that questions assumptions or facilitates a willingness to look from different perspectives. Such a criticality can be described as being non-hegemonic. This implies an acknowledgement of revolutionary ways of knowing and a willingness to move between apparent conflicting ideas in search for other possibilities. Dialogue and openness are paramount; not only in relation to others, but also within one's own mind. It becomes "a way of being as well as a way of thinking" (Burbules \& Berk 1999:2). Bell Hooks seems to share this perspective offered by Burbules and Berk and says that "critical thinking requires us to use our imagination, seeing things from perspectives other than our own and envisioning the likely consequences of our position" (Hooks 2010:10). Critical thought therefore seems to have the potential to help one live a determined life regardless of hampering complexity and the fact that complete understanding forever seems to elude one's mind (Barnett 2000:409). Such thinking also can have a "general humanising effect, across all social groups and classes" (Burbeles \& Berk 1999:2) and seems highly relevant in a country such as South Africa, where the remnants of a previous unequal society still linger. Critical pedagogy refers to education closely based on the principles of critical thinking. It was first practised at the Frankfurt School, and is also closely associated with Freire's (1975) pedagogy of the oppressed. It encourages educators to develop context-specific educational methods where lecturers and students use dialogue to open up the critical consciousness (see Chapter 2 on critical pedagogy).

Johnson and Morris (2010:88-90) mapped relevant citizenship and critical concepts in a framework for critical citizenship education. This map is presented in Table 3.1 and may be used as a guide for critical citizenship education. The map brings four key dimensions of critical citizenship in line with its implications for knowledge, skills, 
values and dispositions. Johnson and Morris believe that critical citizenship education involves developing knowledge of the self - one's sense of identity - in relation to the power structures governing society as a whole, in other words on a political as well as a social level. They are of the opinion that developing critical awareness of the relational nature of the world can aid in developing praxis, which, in the words of Crouch (2007:111-112), "encourages the act of reflecting upon, and reconstructing the constructed world". Adopting praxis assumes a process of making meaning and its accompanying processes that are contingent upon a cultural and social environment. Because praxis is not self-centred, but about acting together with others, and because it is about negotiation and not about acting upon others, it forces the education practitioner to consider more than just the practicalities of teaching and learning.

TABLE 3.1 A framework for critical citizenship education (after Johnson \& Morris 2010:90)

\begin{tabular}{|c|c|c|c|c|}
\hline $\begin{array}{l}\text { Dimensions } \\
\text { of learning }\end{array}$ & $\begin{array}{l}\text { POLITICS } \\
\text { (Ideology) }\end{array}$ & $\begin{array}{l}\text { SOCIAL } \\
\text { (Collectivity) }\end{array}$ & $\begin{array}{l}\text { SELF } \\
\text { (Subjectivity) }\end{array}$ & $\begin{array}{l}\text { PRAXIS } \\
\text { (Engagement) }\end{array}$ \\
\hline Knowledge & $\begin{array}{l}\text { - Knowledge and } \\
\text { understanding } \\
\text { of histories, } \\
\text { societies, } \\
\text { systems, } \\
\text { oppressions } \\
\text { and injustices, } \\
\text { power structures } \\
\text { and macro- } \\
\text { structural } \\
\text { relationships }\end{array}$ & $\begin{array}{l}\text { - Knowledge of } \\
\text { interconnections } \\
\text { between culture, } \\
\text { power and } \\
\text { transformation; } \\
\text { - non-mainstream } \\
\text { writings and } \\
\text { ideas in addition } \\
\text { to dominant } \\
\text { discourses }\end{array}$ & $\begin{array}{l}\text { - Knowledge of } \\
\text { own position, } \\
\text { cultures and } \\
\text { context; } \\
\text { - sense of identity }\end{array}$ & $\begin{array}{l}\text { - Knowledge } \\
\text { of how to } \\
\text { collectively } \\
\text { effect systematic } \\
\text { change; } \\
\text { - how knowledge } \\
\text { itself is power; } \\
\text { - how behaviour } \\
\text { influences } \\
\text { society and } \\
\text { injustice }\end{array}$ \\
\hline Skills & $\begin{array}{l}\text { - Skills of critical } \\
\text { and structural } \\
\text { social analysis; } \\
\text { - capacity to } \\
\text { politicise notions } \\
\text { of culture, } \\
\text { knowledge and } \\
\text { power; } \\
\text { - capacity to } \\
\text { investigate } \\
\text { deeper } \\
\text { causalities }\end{array}$ & $\begin{array}{l}\text { - Skills in } \\
\text { dialogue, } \\
\text { cooperation and } \\
\text { interaction; } \\
\text { - skills in critical } \\
\text { interpretation } \\
\text { of others' } \\
\text { viewpoints; } \\
\text { - capacity to think } \\
\text { holistically }\end{array}$ & $\begin{array}{l}\text { - Capacity to } \\
\text { reflect critically } \\
\text { on one's } \\
\text { "status" within } \\
\text { communities } \\
\text { and society; } \\
\text { independent } \\
\text { critical thinking; } \\
\text { speaking with } \\
\text { one's own voice }\end{array}$ & $\begin{array}{l}\text { - Skills of critical } \\
\text { thinking } \\
\text { and active } \\
\text { participation; } \\
\text { skills in acting } \\
\text { collectively } \\
\text { to challenge } \\
\text { the status } \\
\text { quo; ability to } \\
\text { imagine a better } \\
\text { world }\end{array}$ \\
\hline Values & $\begin{array}{l}\text { - Commitment to } \\
\text { values against } \\
\text { injustice and } \\
\text { oppression }\end{array}$ & $\begin{array}{l}\text { - Inclusive } \\
\text { dialogical } \\
\text { relationship with } \\
\text { others' identities } \\
\text { and values }\end{array}$ & $\begin{array}{l}\text { - Concern } \\
\text { for social } \\
\text { justice and } \\
\text { consideration of } \\
\text { self-worth }\end{array}$ & $\begin{array}{l}\text { - Informed, } \\
\text { responsible and } \\
\text { ethical action } \\
\text { and reflection }\end{array}$ \\
\hline
\end{tabular}




\begin{tabular}{|c|c|c|c|c|}
\hline $\begin{array}{l}\text { Dimensions } \\
\text { of learning }\end{array}$ & $\begin{array}{l}\text { POLITICS } \\
\text { (Ideology) }\end{array}$ & $\begin{array}{l}\text { SOCIAL } \\
\text { (Collectivity) }\end{array}$ & $\begin{array}{l}\text { SELF } \\
\text { (Subjectivity) }\end{array}$ & $\begin{array}{l}\text { PRAXIS } \\
\text { (Engagement) }\end{array}$ \\
\hline Dispositions & $\begin{array}{l}\text { - Actively } \\
\text { questioning; } \\
\text { - critical interest } \\
\text { in society and } \\
\text { public affairs; } \\
\text { - seeking out and } \\
\text { acting against } \\
\text { injustice and } \\
\text { oppression }\end{array}$ & $\begin{array}{l}\text { - Socially aware; } \\
\text { - cooperative; } \\
\text { - responsible } \\
\text { towards self } \\
\text { and others; } \\
\text { - willing to learn } \\
\text { with others }\end{array}$ & $\begin{array}{l}\text { - } \text { Critical } \\
\text { - autonomective; } \\
\text { - responsible } \\
\text { in thought, } \\
\text { emotion and } \\
\text { action; } \\
\text { - forward thinking; } \\
\text { - in touch with } \\
\text { reality }\end{array}$ & $\begin{array}{l}\text { - Commitment } \\
\text { and motivation } \\
\text { to change } \\
\text { society; } \\
\text { - civic courage; } \\
\text { - responsibility for } \\
\text { decisions and } \\
\text { actions }\end{array}$ \\
\hline
\end{tabular}

Obviously, the proposed framework as in Table 3.1 could be used in various ways with more emphasis or less emphasis on certain of its key elements, namely politics/ ideology, social/collective, self/subjective and praxis/engagement. However, Johnson and Morris $(2010: 87,90)$ refer to Westheimer and Kahn $(2004: 237)$, who had indicated that all key elements are vital, because "[c]onceptions of democracy and citizenship have been and will likely always be debated - no single formulation will triumph". The Critical Citizenship module, which we discuss in Chapter 5, uses the post-colonial and post-apartheid context as a framework and therefore has a stronger focus on, for example, social justice, power relations, blackness/whiteness and stereotyping. The framework as suggested by Johnson and Morris can also serve as a template or checklist to identify gaps in one's own integration of critical citizenship education into curricula. Also, because of the prominence of the Christian religion of the students and learners in the sample who were involved in the Critical Citizenship module, the distinction between religion/helping behaviours and critical citizenship became necessary - a key element of what transpired in conversations. It therefore seems clear to us that during the process of working through critical citizenship concepts in a curriculum, different foci (as presented in Table 3.1) might emerge and become more prominent. Emphasis in the framework, given its key elements and its implications for knowledge, skills, values and dispositions, could therefore be constantly shifting in the operational stages of critical citizenship education.

\section{WHY CRITICAL CITIZENSHIP EDUCATION MATTERS IN CURRICULA}

Given the ideas of Johnson and Morris, critical citizenship is taken as the promotion of a common set of shared values. Such values may include tolerance, diversity, human rights and democracy. As an educational pedagogy, critical citizenship education encourages critical reflection on the past and the imagining of a possible 
future shaped by social justice to prepare people to live together in harmony in diverse societies. Critical citizenship education therefore aims at transformation on the personal level of student learning.

To understand the significance of critical citizenship education in higher education curricula it seems important to take its various contexts of inquiry into account. This section explores these contexts, namely higher education as a field of study and curriculum inquiry in higher education as a particular terrain of study within higher education. Hereby we aim to provide motivation for the importance of not merely curricula or the pedagogy of critical citizenship education, but also the need to inquire into and research critical citizenship in higher education curricula.

\section{Higher education and its societal relatedness}

In contrast to curriculum inquiry, research and studies in the field of higher education as a phenomenon is relatively young. Bitzer and Wilkinson (2009) have discussed various international and local developments in higher education as a field of research and study over the last decades. Higher education "officially" became recognised as a formal field of study around the 1930s with the work of Flexner (1930), who compared university systems in the USA. Bitzer and Wilkinson (2009) consider Flexner's work, together with the work of Dressel and Mayhew (1974), as ground-breaking because of the focus on the promotion of research and scholarship in the field. Later, the Encyclopedia of Higher Education, edited by Clark and Neave (1992) and spanning four volumes, added the topic "education and society", under the brief of "analytic perspectives". This pointed to the importance of research into the relation between higher education institutions and their societal contexts.

In the 1970s, Clark identified societal issues such as race, social class and gender specifically related to student achievement and access. He suggested opposing the "dominant instrumental definitions of education with approaches that centre on the values, traditions, and identities - the expressive components - of educational social systems" (Clark 1973:2). McDonough and Fann (2007) and Ferreira and Mendelowitz (2009) also emphasised the dilemmas regarding students who gain access to higher education, but fail to be allowed into the reigning discourse in institutions. In the latter respect, and as we also alluded to in Chapter 1, authors argue that the challenges are ongoing, because "diverse identities and languages have been, to a considerable degree, constructed by decades of racially segregated and oppressive educational, economic and social policies" (Ferreira \& Mendelowitz 2009:78).

In South Africa, the social and political divide of the colonial and apartheid past cannot be easily separated from students and their learning experiences. The 
report from the European Science Foundation (ESF 2008), Higher education looking forward: An agenda for future research, seems relevant here because of its questioning of relationships between present-day social and economic changes, the changes happening in higher education and the roles of academics (also see Bitzer \& Wilkinson 2009). The ESF report, focusing on higher education and society, includes chapters on social change, the socio-political context, interactions and the potential impact of higher education on society. The authors of this report argue that the economic influence of higher education was to receive the main emphasis in the past, while aspects such as social equity, social cohesion and integration were mostly ignored. Higher education curricula and research should therefore better relate to conceptual frameworks such as human capital development theories, theories of power, inequality and social exclusion (ESF 2008:5).

Because higher education proves to influence society and shape the lives of citizens, higher education institutions and their educators are morally bound to contribute to the achievement of a fair and just society. In the section on higher education and the achievement (or prevention) of equity and social justice, the ESF report argues for instance that contributions by higher education tend to fall in two categories: On the one hand, it takes a "liberal" or a "re-allocative" approach where a society is "characterized by high levels of social mobility" and in which civic values and behaviour can be facilitated (ESF 2008:6). On the other hand, it may adopt an approach where "elite reproduction" is followed and the emphasis is on "the reproduction and legitimization of existing social relations and the inequalities they represent" (ESF 2008:10). Critical citizenship education in South African higher education is aimed at the former category, which is working against the perpetuation of existing perceptions and attitudes that stem from a colonial and apartheid past.

Since 1994, South African higher education has transformed considerably, with a strong focus on student access, affordable education, knowledge production, curriculum design, standards and the type of graduates exiting universities (DoE 1996; NCHE 1996; Reddy 2004). After the initial actions towards transformation of the education system in South Africa, research themes in higher education and curriculum studies also changed. Rethinking the classification of themes in higher education studies and research in a South African context, Bitzer and Wilkinson (2009:377) added two categories to Teichler's (2005) original international classification, which included teaching and learning, course/curriculum design, student experience, quality, system policy, institutional management, academic work and knowledge. These two additions were higher education transformation (in South Africa) and higher education and socio-cultural links/relationships/responsibilities. Critical citizenship education has relevance to both of these categories. 


\section{CURRICULUM DEVELOPMENT AND SOUTH AFRICAN EXAMPLES OF CRITICAL CITIZENSHIP EDUCATION}

Connelly and Xu (2008:2) consider Dewey's $(1899,1902)$ books, The school and society and The child and the curriculum, to have provided a sound basis for the terrain of curriculum studies. These works also introduced the use of the term "curriculum". In Tyler's (1949) Basic principles of curriculum and instruction, the curriculum development process came to be structured, starting at the local level with the needs, concerns and objectives of school leaders and the communities in which they work. In the sixties, Taba (1962) extended Tyler's work on curriculum as a structured formula, but, realising the complexity of curriculum development, added philosophical and psychological perspectives. Null (2008) refers to Taba, who had challenged the meaning of "good citizenship" and "living habits" that are accepted without agreeing to or questioning the meaning of the concepts. In turn, Schwab (1969) focused on the practical implementation of curriculum theories, while Null (2008:484) describes Schwab's perspective as curriculum that is "not matters of pure theory", but "[r]ather, curriculum [that] is a social and political activity that requires judgement and action". Schwab's work was heavily influenced by Aristotelian thinking and therefore, according to him, curriculum "exists to shape society in the direction of goodness" and contains "action that serves the public good" (Schwab in Null 2008:485). With Schwab's work, human nature was for the first time used as a central focus in curriculum planning. Within postmodernism, a radical transformation of public institutions was suggested and Apple (1990), among others, brought attention to the "hidden" curriculum, whereby the curriculum could, sometimes unintentionally, perpetuate inequalities of race, class and gender.

The United Nations Millennium Goals Report (UN 2010) and The Earth Charter Initiative (2011) influenced many countries to rethink their curricula globally but also locally. One would assume, especially after the 1994 democratic elections in South Africa, that critical citizenship education would have gained importance much faster, but some authors suggest that "despite its post-apartheid trajectory, higher education in South Africa, for most part, has circumvented debates on undergraduate core curricula" (University of Fort Hare 2011:1).

Critical citizenship education, as mentioned before, could include a variety of aspects such as the promotion of a common set of shared values including tolerance, diversity, human rights and democracy. Some international and local departments at higher education institutions already incorporate these critical citizenship characteristics into their curricula. Critical citizenship could be intrinsic to a course itself as, for instance, in some courses in arts and social sciences programmes. To further demonstrate 
why critical citizenship is important in higher educational curricula, we briefly refer to local (a South African university's) examples of incorporating critical citizenship as part of its core curriculum, as a compulsory signature learning experience or as voluntary separate courses.

As a prominent example, the University of Fort Hare launched its core curriculum under the title of "Life, Knowledge, Action (LKA): Grounding Programme" in 2009 and expanded it further in 2010. The aim of the programme is described as "a trans-disciplinary teaching and learning experience based on a just, humanizing and collaborative pedagogy that builds on students' social capital as a way of developing compassionate, socially-engaged, critical and responsible glocal [global and local] citizens" (University of Fort Hare 2011 :2). Table 3.2 presents the knowledge, skills and values as promoted by the LKA grounding programme of the Fort Hare University's compulsory undergraduate core curriculum.

TABLE 3.2 Knowledge, skills and values (adapted from University of Fort Hare 201 1)

\begin{tabular}{|c|c|c|c|c|}
\hline CORE NOTIONS & \multicolumn{3}{|c|}{ KNOWLEDGE STREAMS } & SKILLS STREAMS \\
\hline \multirow{5}{*}{$\begin{array}{l}\text { - Society } \\
\text { - Democracy } \\
\text { - Non-discrimination } \\
\text { - Loving, Living and } \\
\text { Learning (including } \\
\text { HIV/AIDS) } \\
\text { - Transdisciplinarity } \\
\text { - Social engagement } \\
\text { - Humanising } \\
\text { pedagogy/Student } \\
\text { participation }\end{array}$} & $\begin{array}{l}\text { Citizenship, } \\
\text { Society \& } \\
\text { Democracy }\end{array}$ & $\begin{array}{l}\text { Science, } \\
\text { Technology \& } \\
\text { Environment }\end{array}$ & $\begin{array}{l}\text { Economics, } \\
\text { Education \& } \\
\text { Development }\end{array}$ & \multirow{5}{*}{$\begin{array}{l}\text { - Social inquiry } \\
\text { - Scientific inquiry } \\
\text { - Reading and } \\
\text { Writing } \\
\text { - Political, } \\
\text { Electoral, Social, } \\
\text { Cultural and } \\
\text { Environmental } \\
\text { literacy } \\
\text { - Information and } \\
\text { Financial literacy } \\
\text { - Building an } \\
\text { argument } \\
\text { - Communication } \\
\text { - Cooperative } \\
\text { learning } \\
\text { - Emotional } \\
\text { intelligence } \\
\text { - Critical thinking } \\
\text { and Dialogue }\end{array}$} \\
\hline & $\begin{array}{l}\text { U1: Life, Law, } \\
\text { Regulation and } \\
\text { Society }\end{array}$ & $\begin{array}{l}\text { U3: Science and } \\
\text { Technology }\end{array}$ & $\begin{array}{l}\text { U5: Education } \\
\text { and } \\
\text { Globalisation }\end{array}$ & \\
\hline & $\begin{array}{l}\text { U2: Citizenship, } \\
\text { Democracy and } \\
\text { Human Rights }\end{array}$ & $\begin{array}{l}\text { U4: Environment } \\
\text { and Society }\end{array}$ & $\begin{array}{l}\text { U6: Economics } \\
\text { and } \\
\text { Development }\end{array}$ & \\
\hline & \multicolumn{3}{|c|}{ VALUES AND PRINCIPLES } & \\
\hline & $\begin{array}{l}\text { - Equality } \\
\text { - Healthy } \\
\text { lifestyle } \\
\text { - Commitment } \\
\text { to self- } \\
\text { development } \\
\text { - Honesty } \\
\text { - Accuracy } \\
\text { - Hospitality }\end{array}$ & $\begin{array}{l}\text { - Integrity } \\
\text { - Reliability } \\
\text { - Trust } \\
\text { - Vitality } \\
\text { - Playfulness } \\
\text { - Curiosity } \\
\text { - Authenticity } \\
\text { - Compassion }\end{array}$ & $\begin{array}{l}\text { - Efficiency } \\
\text { - Enthusiasm } \\
\text { - Agency } \\
\text { - Responsibility } \\
\text { - Love, } \\
\text { Optimism } \\
\text { - Rights, } \\
\text { - Choices } \\
\text { - Respect }\end{array}$ & \\
\hline
\end{tabular}

Similarly, a core curriculum module was introduced at the University of the Free State (UFS) in 2012, titled UFS 101. This compulsory module aims to teach firstyear students to look at local and global challenges from various perspectives and "engage critically with the newest thinking nationally and internationally in fields 
such as nanotechnology, law and history [...] [where] students will also learn more about themselves and confront the boundaries in their thinking" (UFS 2012). One pertinent aim of the module is to promote social cohesion among students.

The UFS 101 core curriculum, compulsory for all first-year students, includes dealing with questions such as: Is Google making us stupid?, which requires students to position themselves in a global world and to reflect on their role in addressing global and societal problems. Another question concerns how students deal with a violent past. It is pointed out that the South African history persistently recurs as a sensitive societal issue among South Africans. Other questions include: What does it mean to be fair? Here students explore, for example, the Soobramoney ${ }^{4}$ case to facilitate a discussion on "what is fair" in society. This theme exposes students to legal arguing and reflects on matters of fairness. Another example asks, "Did God really say?", which involves students being exposed to classic sets of passages from the Old Testament in the Bible relating to concepts of good and evil, asking questions on the spread and communication of knowledge, the power of written text and the meanings that the everyday person gives to religious texts (UFS 2012).

A third example is the University of Cape Town's course on "Global citizenship: Learning for social justice - global debates, local voices" (HAESDU 2012). This extra-curricular course is interactive, free and optional, and includes modules such as "Global debates, local voices", which handle topics such as development in poor societies, Africa in a globalised world, war and peace, and climate change. The courses are facilitated by course coordinators and tutors and include events, lectures and workshops, but also online coursework and online interaction. The cost of the programme is sponsored by the Vice-Chancellor's Strategic Fund.

At Rhodes University, compulsory workshops in small groups for first-year students focus on sexuality, substance abuse, coping with stress, diversity, equity, human rights, tolerance and respect for individual differences (Rhodes University 2012). Smith (2011:9) refers to a common course called "Where leaders learn", which Rhodes University is developing and which includes compulsory critical citizenship education for all undergraduates in combination with other modules during their studies.

The University of the Western Cape (UWC) has recently developed a Charter of Graduate Attributes and each department and faculty is currently in a process

4 Mr Soobramoney, who suffered from ischaemic heart disease and cerebro-vascular disease, made a case against the Minister of Health in November 1997 when the Addington Hospital (a state hospital) informed him that he did not qualify for admission. The hospital, because of limited resources, only admits patients that can be cured in a short period of time. Mr Soobramoney could not be cured in a short period of time and needed ongoing treatment, which the hospital refused to provide (SAFLII 2012). 
of "making sense of the Graduate Attributes in terms of their own outcomes and aims" (UWC 2014). UWC describes graduate attributes as "qualities, attitudes and dispositions that graduates should possess, in full or part, when they have completed their course of study" (UWC 2014). Graduate attributes that are focused on at UWC include having a critical attitude towards knowledge; to adopt critical citizenship for the social good; to be inquiry-focused and knowledgeable; to be autonomous and collaborative; to be ethically, environmentally and socially aware and active; to be skilled communicators; to have interpersonal flexibility; and to demonstrate confidence to engage across differences.

At our own institution, Stellenbosch University, a "Signature Learning Programme" (Smith 2011:1) for all first-year students was investigated and adopted in 2011. Different options have been evaluated, for instance an option to include citizenship modules in existing curricula, or to establish a core citizenship curriculum to be followed by all students across faculties and disciplines. The focus on graduate attributes that students should acquire while studying was also investigated in 2011 (Van Schalkwyk, Herman \& Muller 2010). In 2013, graduate attributes were incorporated into Stellenbosch University's Teaching and Learning Strategy 2014-2018 (SU 2013; 2012) (see Table 3.3) and a set of attributes were formulated (Table 3.4). The Centre for Teaching and Learning of Stellenbosch University held workshops and presentations on graduate attributes and invited lecturers to incorporate graduate attributes into their courses. Even though lecturers attended the workshops, practically incorporating it into their courses seems to be a stumbling block. Incorporating critical citizenship into existing curricula involves a long process of convincing lecturers to walk the path of critical self-reflection and to incorporate critical citizenship into their curricula. This, we believe, could result in a slower process of critical citizenship learning, but has the potential to have a more lasting effect. A course followed over a period of three to four years has the potential to be more effective, because it incorporates time to reflect and grow.

TABLE 3.3 Teaching and Learning Strategy 2014-2018 (SU 2013)

\begin{tabular}{|l|l|l|l|l|l|}
\hline \multicolumn{2}{|c|}{ Stellenbosch University: Summary of the Teaching and Learning Strategy 2013-2017 } \\
\hline & $\begin{array}{l}\text { Graduate } \\
\text { Attributes }\end{array}$ & $\begin{array}{l}\text { An enquiring } \\
\text { mind }\end{array}$ & $\begin{array}{l}\text { An engaged } \\
\text { citizen }\end{array}$ & $\begin{array}{l}\text { A dynamic } \\
\text { professional }\end{array}$ & $\begin{array}{l}\text { A well- } \\
\text { rounded } \\
\text { individual }\end{array}$ \\
\cline { 3 - 6 } & $\begin{array}{l}\text { Teaching and } \\
\text { Learning at SU }\end{array}$ & $\begin{array}{l}\text { A critical and } \\
\text { scholarly } \\
\text { academic }\end{array}$ & $\begin{array}{l}\text { An engaging } \\
\text { curriculum } \\
\text { design }\end{array}$ & $\begin{array}{l}\text { A dynamic } \\
\text { delivery }\end{array}$ & $\begin{array}{l}\text { An enriched } \\
\text { campus } \\
\text { experience }\end{array}$ \\
\hline $\begin{array}{lll}\text { Strategic } \\
\text { Priorities }\end{array}$ & $\begin{array}{l}\text { Professionalisation } \\
\text { of the scholarly } \\
\text { teaching role }\end{array}$ & $\begin{array}{l}\text { Realisation of } \\
\text { the graduate } \\
\text { attributes }\end{array}$ & $\begin{array}{l}\text { IT-enhanced } \\
\text { learning } \\
\text { model }\end{array}$ & $\begin{array}{l}\text { Proactive } \\
\text { support for a } \\
\text { diverse student } \\
\text { cohort }\end{array}$ & $\begin{array}{l}\text { Programme } \\
\text { renewal }\end{array}$ \\
\hline
\end{tabular}


ENGAGING HIGHER EDUCATION CURRICULA

TABLE 3.4 Stellenbosch University graduate attributes (SU 2012)

\begin{tabular}{|l|l|}
\hline Attribute & Descriptors \\
\hline An enquiring mind & $\begin{array}{l}\text { - Lifelong learner } \\
\text { - Critical and creative thinker }\end{array}$ \\
\hline - Exercises responsibility for learning and using knowledge \\
\hline An engaged citizen & $\begin{array}{l}\text { - Leader and collaborator } \\
\text { - Social entrepreneur }\end{array}$ \\
\hline - Effective in a diverse environment
\end{tabular}

Obviously, a core curriculum provides opportunities to show that an institution is "doing something" about transformation. The question is, however, whether students will take a core curriculum course seriously if it is separate from their main programme of study, and also whether they will be able to identify the links between what they learn in the core curriculum and their own field of study. Integrating the core curriculum into students' main field of study seems crucial, as this allows students the opportunity to engage with relevant critical citizenship issues in an integrated way. Issues of critical citizenship are seldom encountered in isolation, but mostly in daily interaction in classrooms, student residences, student workplaces, in service learning community settings, during social events and at home. It is therefore essential to, in some way, try to simulate confronting the complexity of everyday life in the classroom.

Community interaction has gained significant ground as a core function in Higher Education (HE) globally. At Stellenbosch University community interaction has become very prominent during the last decade with a focus on community interaction through teaching, learning and research. Service Learning (SL) is curriculum-based and credit-bearing community interaction that benefits the community, but students also learn from the interaction. SL could contribute to the paradigm shift of the Higher Education Institution (HEI) contributing directly to society and move away from the ivory tower mentality. Learning and research is directly related to real-life issues and therefore students could start to see that they can play a role in society and that what they learn in the curriculum is useful and meaningful. 
A "top-down" approach to implementing citizenship education in the curriculum, where lecturers are forced to include such material, is usually driven by individuals or groups with a specific goal in mind. The danger of such an approach is that staff members who are forced to conform might not change their own attitudes and perceptions, and would therefore teach something that they do not necessarily believe in. Introducing a core curriculum in this way would not necessarily transform the university. It could, in fact, divert attention away from internal social transformation issues within the university.

Alternatively, a "bottom-up" approach, where lecturers buy into the concept of their own will, may involve a much slower process, but can yield more positive results. Such an approach could provide space for deep self-reflection and for dealing with emotions of the past. This could be achieved by creating space for conversations within the context of a curriculum about past issues and it is the process of participation and possible healing that follows from this which seems essential. Apple and Beane (2007:19) stress the need for "democratic participation" in curricula through which students (and lecturers) could "shed the passive role of knowledge consumers and assume the active role of 'meaning makers'". Hattam (2004:2) also proposes that mutual vulnerability aims to "heal the effects of traumatic events that produce guilt, anxiety, resentment and injustice". Quite rightly, Harrison (in Foerst 1999:383) has remarked that it is not about what we feel, but rather about "what do I do with what I feel?" A bottom-up approach is therefore suggested as more democratic, inclusive and holistic - a position emphasised by several authors (see Petersen \& Osman 2013; Pribbenow 2005; Reeb 2010).

All the examples we have cited thus far seem to establish that, even though the manner in which critical citizenship is incorporated into higher education curricula varies among institutions, the importance of the integration of concepts relevant to social justice and democracy into fields of study at South African higher education institutions seems critical.

\section{CONCLUSION}

What we have established in this chapter points at four interlinked issues: the legacies of the past and higher education policy changes after 1994, links between curriculum development and societal change, why critical citizenship education proves to be important in such processes, and examples from South African universities where critical citizenship was introduced in core modules or courses.

On the issue of colonial and apartheid legacies in South Africa we have pointed out that:

- it had devastating effects on higher education institutions and their students alike; 


\section{ENGAGING HIGHER EDUCATION CURRICULA}

- after 1994, higher education legislation and policies had been introduced that facilitated institutional and curriculum transformation to address these legacies; and

- higher education institutions are increasingly investigating student capability and attribute theories to facilitate student learning for a new democratic South African future.

On the links between curricula and broader societal change we have also highlighted the following:

- Internationally, there are constant movements to relate curricula closer to societal issues and problems.

- Public higher education institutions are increasingly expected to make relevant contributions for the public good.

- International higher and education research agendas do not only focus on the potential economic contributions of higher education institutions, but also on important social issues such as equity, social cohesion and relational human capital.

What this chapter has brought to bear is that a critical citizenship perspective in curricula ideally has to include the following:

- A clear definition of the concept of critical citizenship

- Substantial links to critical thinking and critical pedagogy

- Some or other guiding framework for critical citizenship education

- Learning activities towards identity development that help students to see themselves as contributing to a more just and equal society.

In the final analysis, we have provided some examples from South African universities where critical citizenship was introduced into core curricula, indicating that:

- different models are at work to introduce critical citizenship at South African universities and that such models may aptly reflect the past, present and future institutional contexts of particular universities; and

- there may be not one best way or model of introducing critical citizenship into university curricula, as such initiatives may vary between "top-down", compulsory courses at the first-year level and "bottom-up" approaches that integrate critical citizenship into degree programmes at different levels of study.

The next chapter emphasises the point that higher education curricula need to be actively engaged in order to become and remain vibrant, especially within emerging 
democracies such as in South Africa. We also propose that in doing so, critical citizenship education remains an important element in curricula against a background of what is expected from public universities. Four kinds of learning to inform critical citizenship education are suggested, namely psychosocial, transformational, sociopolitical and multicultural learning. 